\title{
Protein, carbohydrate, lipid concentrations and HSP 70-HSP 90 (stress protein) expression over an annual cycle: useful tools to detect feeding constraints in a benthic suspension feeder
}

Received: 29 October 2004 / Revised: 12 July 2005/ Accepted: 13 July 2005 / Published online: 7 October 2005

(C) Springer-Verlag and AWI 2005

\begin{abstract}
In the present paper we suggest an effect of seasonal variations in food availability on two ecophysiological parameters in a warm temperate benthic suspension feeder: the tissue concentrations of proteins, carbohydrates and lipids on the one hand, and the expression of stress proteins (HSP 70 and 90, inducible and/or constitutive) on the other hand. The concentrations of biomacromolecules have already been used to describe bentho-pelagic and reproductive processes, but this is the first time that stress protein expression is suggested to be directly related with food constraints in marine organisms. Paramuricea clavata (Cnidaria: Gorgonacea) express HSP 70 and 90 (constitutive and/ or inducible) throughout the seasonal cycle, and HSP 70 levels are twice as high as the levels of HSP 90. In summer and autumn, when seston availability to suspension feeders was low, $P$. clavata showed low levels of carbohydrates and lipids, but high levels of HSPs expression. The levels of HSP 70 and 90 expression fit with negative exponential functions of carbohydrate and lipid concentrations. We suggest a direct effect of food availability on the studied ecophysiological parameters while the effect of temperature may be rather indirect. HSP expression as well as the tissue concentrations of carbohydrate and lipids may be used as biomarkers of environmental changes and seston availability to benthic suspension feeders.
\end{abstract}

Keywords Protein-carbohydrate-lipid - HSP · Feeding constraints $\cdot$ Seasonal cycle $\cdot$ Suspension feeders

Communicated by H.-D. Franke

S. Rossi $(\bowtie) \cdot$ J.-M. Gili

Institut de Ciéncies del Mar (CSIC),

Passeig Marítim de la Barceloneta 37-49,

Barcelona 08003, Spain

E-mail: srossi@icm.csic.es

M. J. Snyder

Bodega Marine Laboratory, P.O. Box 247, 2099 Westside Road, Bodega Bay, CA 94923, USA

\section{Introduction}

Sessile suspension feeders dominate hard and soft substrates of shelf benthic communities. These organisms feed on a wide spectrum of particles transported horizontally and vertically (Wotton 1994; Wildish and Kristmanson 1997). Sessile organisms interact with currents at individual, colony, population, and community levels, efficiently capturing available prey (Gili and Coma 1998) and coupling their biological cycles to stochastic environmental changes (Coma et al. 2001).

In benthic invertebrates, life cycles can be interpreted as cumulative responses to environmental fluctuations through the annual cycle (Cavaletto and Gardner 1998; Brockington et al. 2001). For example, tissue proteincarbohydrate-lipid concentrations are an excellent tool to understand the relationships between the feeding and reproductive cycles of benthic organisms and environmental factors in the water column (Cavaletto et al. 1996; Cavaletto and Gardner 1998). On the other hand, environmental changes are reflected in cellular signals. The study of such signals has received little attention (except for the temperature-HSP relationship) but might contribute significantly to an understanding of environment-species relationships.

A physiological parameter related with environmentspecies relationships in laboratory and field experiments is stress protein expression (heat-shock protein, HSP) (e.g. Hoffman and Somero 1996; Minier et al. 2000; Snyder and Rossi 2004). It is known that HSPs are important for organisms that under natural conditions encounter high physical stress such as temperature shifts. Whether the induction of HSPs by stress is widespread among organisms under natural conditions is still poorly known (see Feder and Hofmann 1999, for a review). In situ HSP expression studies have been performed on very few species (e.g. Hofmann and Somero 1995; Helmuth and Hofmann 2001; Rossi and Snyder 2001; Snyder and Rossi 2004). Only very recently the stress protein response has been related directly or 
indirectly to ecological processes other than heat shock (Minier et al. 2000; Rossi and Snyder 2001).

A relationship between food deprivation and HSP expression is known from laboratory studies (e.g. Plakidou-Dymock and McGivan 1994; Lee et al. 1999; Lewis and Hughes-Fulford 2000). In the present paper, a warm temperate suspension feeder from a hard bottom community has been studied to test whether HSP expression through the annual cycle is related with feeding constraints. It is well known that seston availability to most suspension feeders is markedly seasonal in warm temperate seas (Grémare et al. 1997). Two physiological parameters were examined in the gorgonian Paramuricea clavata: (1) Protein, carbohydrate and lipid concentrations, and (2) HSP 70 and HSP 90 protein expression (inducible and/or constitutive). The gorgonian species chosen is very abundant on hard bottom substrates in the Mediterranean Sea and is considered an essential element of the three-dimensional structure of the sublittoral benthic community (Gili and Ros 1985). The biology of $P$. clavata has been extensively studied during the last decade (e.g. Weinberg 1978; Mistri and Ceccherelli 1994; Coma et al. 1998a, 2002). Furthermore, stress protein expression in $P$. clavata tissue cannot be related with highly fluctuating temperatures (heat shock response), because the cnidarian lives at 15-60 m depth (Gili and Ros 1985) and changes in temperature in the spring-summer period do not exceed $2-3^{\circ} \mathrm{C}$. Due to the three-dimensional structure of the colonies, HSP expression cannot be related with space competition processes previously determined in other cnidarians (Rossi and Snyder 2001). The sampling zone (a marine protected area) is considered free of pollutants (ACA 2001), so pollution effect on HSP expression can be excluded. The goal of this paper was to conduct the first combined study of both parameters (i.e. protein, carbohydrate and lipid concentrations on the one hand, and HSP 70 and 90 expression on the other hand) that may be related to seasonal changes in environmental factors such as the quality/quantity of seston available to a benthic sessile suspension feeder.

\section{Material and methods}

Protein, carbohydrate and lipid tissue concentrations as well as HSP 70 and HSP 90 protein expression in the gorgonian Paramuricea clavata were determined monthly from February 1997 to February 1998 at the Medes Islands $\left(40^{\circ} 02^{\prime} 55^{\prime \prime} \mathrm{N}, 3^{\circ} 13^{\prime} 30^{\prime \prime} \mathrm{E}\right.$, north western Mediterranean Sea). A population living on a boulder $18 \mathrm{~m}$ depth was sampled by SCUBA divers as follows: 20 colonies $>40 \mathrm{~cm}$ height (ten male and ten female mature colonies) were tagged in February 1997, and their sex was identified in May 1997 according to Coma et al. (1995a). Samples taken prior to May could be sexed retrospectively. Apical branches were cut off, preserved in plastic bags and transported to the coast in a cooler with sea water and plastic ice-coolers $\left(10^{\circ} \mathrm{C}\right)$.
No more than $30-40$ min passed from the sampling in the field until samples were frozen in liquid nitrogen (cryovials). The branches were then transported to the main laboratory, and stored at $-80^{\circ} \mathrm{C}$.

Water temperature profiles were made every $3-5$ days with an inverted thermometer, according to Cebrián et al. (1996), $100 \mathrm{~m}$ apart from the sampling area (Estartit meteorological station). Wave height was recorded each day by repetitive counting of the wave crash on a rock with a ruler (precision: $0.2 \mathrm{~m}$ ).

To determine seston availability near the bottom, water was sampled along with $P$. clavata tissue, $30 \mathrm{~m}$ apart from the gorgonian population (Rossi 2002), in the same channel where the suspension feeders settled. The main currents in this place flow from sampling site in the water column to the studied gorgonian population (Pascual et al. 1995). Biochemical parameters were determined from natural seawater (22-24 1), collected by SCUBA diving every 15 days. The water was carefully sampled with the aid of 21 plastic bags, $0.2-0.5 \mathrm{~m}$ above the horizontal rocky surface, avoiding any movement that could result in a resuspension of the sediment. Once on the boat, the bags were emptied into 51 bottles which were kept on ice coolers $\left(10^{\circ} \mathrm{C}\right)$ until arrival in the laboratory (no more than 30-40 min after sampling). After each sampling, the plastic bags were rinsed with deionized water. While processing, seawater samples were always maintained at $10^{\circ} \mathrm{C}$ in the dark. We present here only near bottom seston protein concentration (for further data on environmental factors and near bottom seston characteristics in the same area and at the same time, see Rossi 2002 and Rossi et al. 2003).

Seston protein concentration is considered a useful measure for the quality of matter (compared with particulate organic carbon and nitrogen; Arin et al. 1999). Estimation of the total particulate protein concentration was made from three $1,400 \mathrm{ml}$ seawater replicates filtered through pre-combusted $\mathrm{GF} / \mathrm{F}$ filters that were immediately frozen in liquid nitrogen and maintained at $-80^{\circ} \mathrm{C}$ until processing. Protein concentration was estimated spectrophotometrically by the Lowry et al. (1951) protocol with minor changes. The filters were extracted by grinding them in the cold on $1 \mathrm{~mol}^{-1} \mathrm{NaOH}(2 \mathrm{ml})$ with a tissue-grinding homogenizer. The assay was performed on $0.5 \mathrm{ml}$ of the homogenate. After the color reaction, the mixture was centrifuged at $3,000 \mathrm{rpm}$ to avoid the glass fiber interference in the $750 \mathrm{~nm}$ wave length reading (UVIKON 923 spectrophotometer). Bovine serum albumin (Sigma) was used as standard.

Protein, carbohydrate and lipid tissue concentration

Organic matter $(\mathrm{OM})$ of primary branches was calculated taking monthly $10-15 \mathrm{mg}$ of the tissue $(N=20$, dry weight) and ashing for $4 \mathrm{~h}$ at $500^{\circ} \mathrm{C}$. The difference between dry weight and ash weight was the organic matter (Slattery and McClintock 1995). 
The protein, carbohydrate and lipid concentrations were determined with lyophilized branches (freeze-dried $12 \mathrm{~h}$ at $-110^{\circ} \mathrm{C}$ and 100 mbar pressure), and stored at $-20^{\circ} \mathrm{C}$. Twenty milligram portions of each dried branch $(N=20$ branches each month; 15-30 polyps per branch plus connective tissue, peeled branch, no axis; weighed to $0.01 \mathrm{mg}$ ) were used in each of the following analyses. Proteins were quantified using the Lowry et al. (1951) method, and tissues were homogenized in $6 \mathrm{ml} 1 \mathrm{~mol}^{-1}$ sodium hydroxide. Carbohydrates were quantified using the Dubois et al. (1956) method for the 20 colonies each month (homogenized in $6 \mathrm{ml}$ double distilled water). Lipids were quantified using the Barnes and Blackstock (1973) method $(N=20$, homogenized with $4 \mathrm{ml}$ chloroform-methanol $(2: 1 \mathrm{~V}: \mathrm{V}))$. Results are presented in $\mu \mathrm{g}$ protein/carbohydrate/lipid $\mathrm{mg}^{-1} \mathrm{OM}$.

\section{HSP 70 and HSP 90 measurements}

From the 20 tagged colonies, four males and four females were assayed for stress protein levels during the 13 month period. It has been demonstrated that $30 \mathrm{~min}$ at $10^{\circ} \mathrm{C}$ does not induce HSP expression in cnidarian tissues (Rossi and Snyder 2001, Snyder and Rossi 2004). The following protocol was used in western immunoblotting for HSP 70 and HSP 90 expression. Frozen samples (stored at $-80^{\circ} \mathrm{C}$ ) were individually homogenized in $0.2 \mathrm{ml}$ of buffer $\mathrm{K}$ containing $5 \mathrm{mmol}^{-1}$ sodium phosphate, $40 \mathrm{mmol} 1^{-1}$ HEPES, pH 7.4, $5 \mathrm{mmol} 1^{-1}$ magnesium chloride, $70 \mathrm{mmol} 1^{-1}$ potassium gluconate, $150 \mathrm{mmol} 1^{-1}$ sorbitol, and $1 \%$ SDS. Homogenates were centrifuged $10 \mathrm{~min}$ at $10,000 \mathrm{~g}$, and the supernatants were combined with equal volumes of SDS sample buffer (Laemmli 1970) and boiled for $5 \mathrm{~min}$. Supernatant protein levels were determined by BioRad DC assay (which follows the Lowry et al. 1951 method), and $20 \mu \mathrm{g}$ of colony protein was loaded in each gel lane. Discontinuous SDS gels $(1 \mathrm{~mm})$ were $6.2 \%$ for the stacking gel and $12 \%$ for the resolving gel. After running for $2 \mathrm{~h}$ at 150 volts, SDS gels were electroblotted onto PDVF membranes (for $1 \mathrm{~h}$ at 100 volts). The protein band quality of each western blot was checked by visualization of proteins by Ponceau S staining. HSP 70 and HSP 90 proteins were detected using mouse monoclonal anti-HSP 70 (SPA-822), and anti-HSP 90 (SPA-830; both from StressGen, Victoria, B.C.). The use of SPA822 HSP 70 antiserum may underestimate the number of HSP 70 isoforms, and consequently may explain the finding of a single HSP 70 protein by our methods. However in larval lobsters, Homarus americanus, juvenile abalone, Haliotis rufescens, and adult mussels, Mytilus galloprovincialis, respectively (Snyder and Mulder 2001; Snyder et al. 2001) 3-4 different HSP 70 isoforms could be revealed with the same antiserum. The secondary antibody was goat-anti-mouse IgG, conjugated to peroxidase (Sigma). Visualization was performed using ECL reagents (Amersham) and exposure of blots to x-ray film. Blot band intensities were compared by scanning the $\mathrm{x}$-ray films and analysed with the NIH Image software package. For each blot, $50 \mathrm{ng}$ of standard protein (human HSP 70 or bovine HSP 90, StressGen) was included. Scanned intensities of all HSP bands were compared against the intensities of the HSP protein standards from each blot. Each scanned NIH Image is divided by the intensity of the HSP standard from that particular western blot.

HSP 70 and 90 expression has been previously reported in cnidarians by others using the same or similar techniques (Miller et al. 1992; Sharp et al. 1994; Black et al. 1995; Fang et al. 1997; Sharp et al. 1997; Wiens et al. 2000; Rossi and Snyder 2001; Snyder and Rossi 2004).

\section{Statistics}

ANOVA with post-hoc Tukey tests were made using the STATISTICA 6.0 software package, grouping both biochemical levels and HSP concentrations in (months) $\times$ (sex). A simple standard correlation was made to fit water temperature (20 m depth) and HSP 70 and 90 expression, and separately for the HSP 70 and HSP 90 expression relationships. Biochemical parameters (protein, carbohydrate and lipid concentrations) and the HSP 70 and 90 (stress proteins expression) were fitted using different regression models (i.e. linear, exponential, polynomial, etc.) using STATISTICA 6.0 software package to determine (1) if there was some relationship, and, if so, (2) which kind of relationship explained most of total variance.

\section{Results}

Minimum water temperatures were reached in February-March, maximum in August-September (Fig. 1). Minimum wave height was recorded in

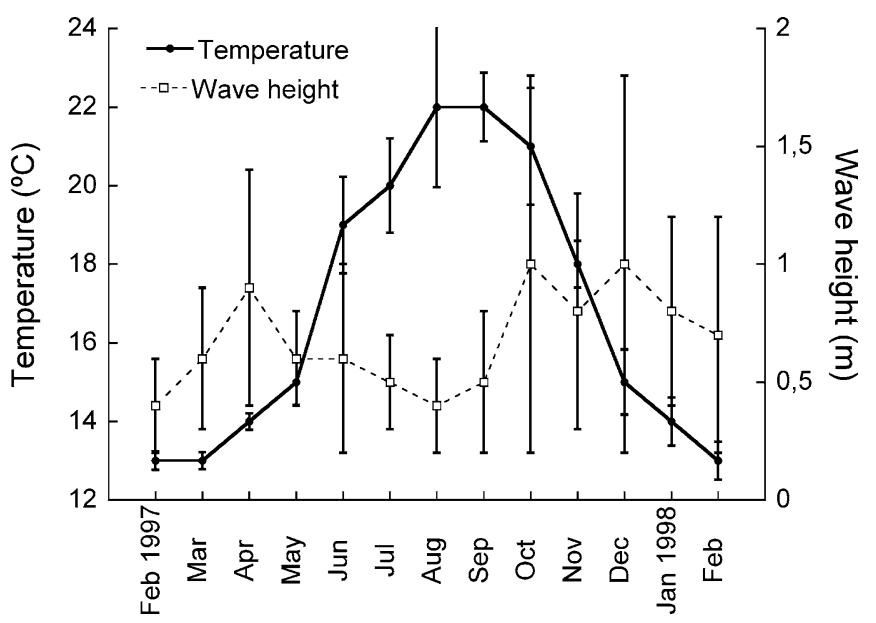

Fig. 1 Temperature $(20 \mathrm{~m} \mathrm{depth})$ and wave height (monthly means \pm SD) $100 \mathrm{~m}$ apart from the sampling station, from February 1997 to February 1998 
February 1997 and August, whilst maximum was recorded in October and December (Fig. 1). From July to September, temperatures were high and wave height low, so the thermocline was well established and water movements were weak. Shifts in temperature at $20 \mathrm{~m}$ depth were (maximum) $2^{\circ} \mathrm{C}$ in these months. In November and December, temperature was lower, and no shifts were recorded (the thermocline disappeared); waves were higher and more irregular than in the summer period, promoting water movements.

Seston protein concentration was minimal in September, and maximal in June (Fig. 2). Seston proteins showed high concentrations from February to August 1997. In September 1997 seston protein concentration dropped, remained low until January 1998, then increased again.

Throughout the year, there were no differences between sexes nor between months in the organic matterrefractory matter (mainly $\mathrm{CaCO}_{3}$ spicules) proportions in the tissue of primary branches (two-way ANOVA $\left.F_{12,249}=0.958, P=0.449\right)$. The annual mean weight of inorganic matter was $596 \pm 45 \mu \mathrm{g} \mathrm{mg}^{-1}$ dry tissue weight ( $\approx 60 \%$ of the dry weight).

The tissue concentration of protein and carbohydrate varied monthly but there was no difference between male and female colonies (Fig. 3a, b and Table 1a, b). Tukey post-hoc test showed two protein maxima, in FebruaryJuly 1997 and in October-November 1997. February 1998 was not different from February 1997.

Minimum values in carbohydrate concentration were present from August to December, whilst maximum values were recorded in February-March. Tukey posthoc test showed no differences in carbohydrates between February 1997 until April 1997 and January-February 1998. However, there were significant differences compared to the July-December period.

Lipid levels were significantly different between male and female colonies from March to June and in both

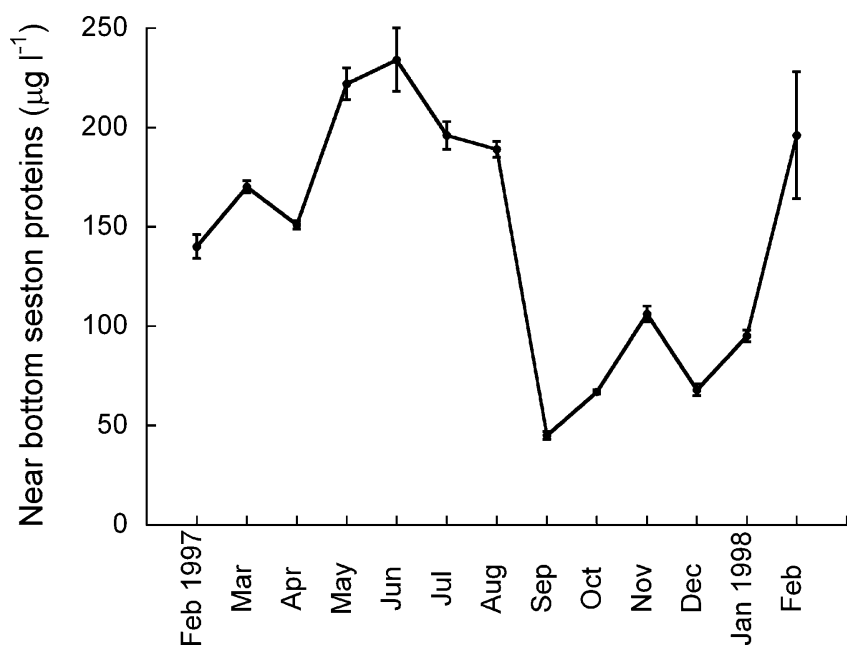

Fig. 2 Near bottom seston protein concentration (monthly means \pm SD), from February 1997 to February 1998
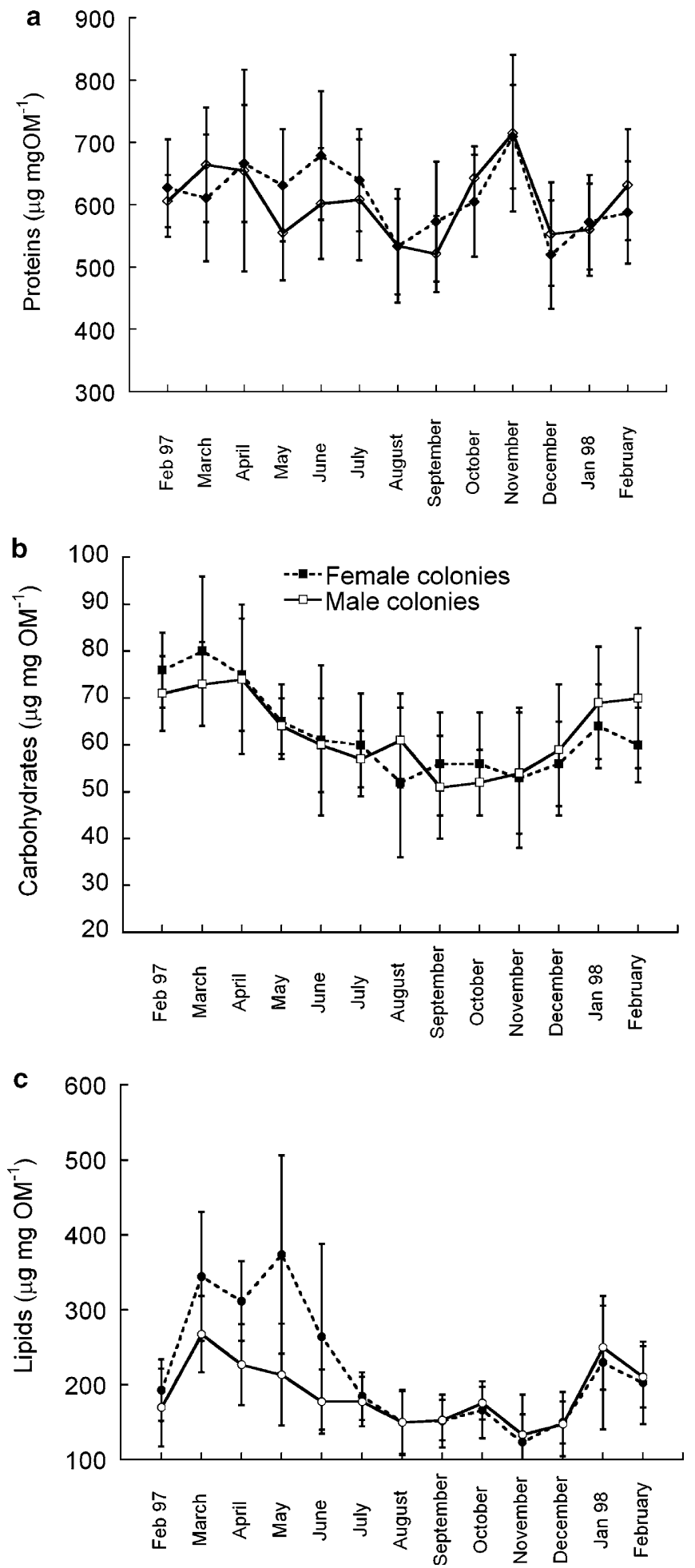

Fig. 3 Protein (a), carbohydrate (b) and lipid (c) concentrations over 1 year in the tissues of male (solid line, white symbols) and female (dashed line, black symbols) Paramuricea clavata, (monthly means $\pm \mathrm{SD}$ ); $O M$ organic matter

sexes the levels varied monthly (Fig. 3c and Table 1c). Maximum levels of tissue lipids were recorded in winterspring, minimum in summer-autumn. The Tukey post- 
Table 1 Analysis of variance (factors: sex, month) for the tissue concentrations of proteins (A), carbohydrates (B), lipids (C), HSP 70 (D) and HSP 90 (E) in the gorgonian Paramuricea clavata (Tukey post-hoc test)

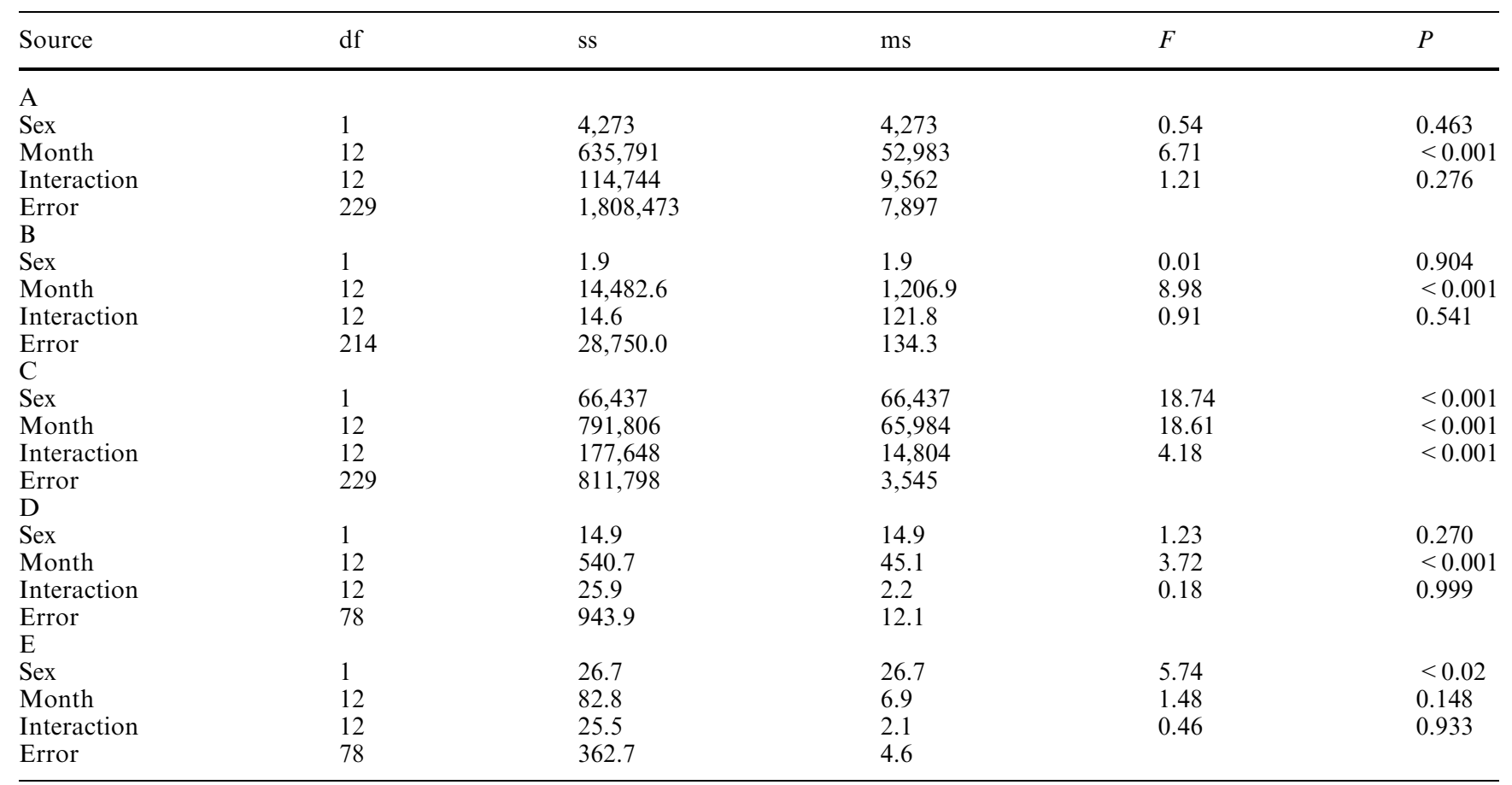

hoc test showed that in females, lipid concentrations in March-June 1997 and in January-February 1998 were significantly higher than in July-December 1997. Such differences were less pronounced in males, but in males also the July-December 1997 period differed from both the periods March-May 1997 and January-February 1998.

Paramuricea clavata expressed HSP 70 (constitutive and/or inducible) throughout the seasonal cycle (Fig. 4a). The monthly variability expressed by the tested colonies was high. No differences between male and female colonies were found through the annual cycle (Table 1d). Minimum values were recorded in June, maximum in September. Tukey post-hoc analysis showed that HSP 70 expression in August-December 1997 was different from that during the rest of the year. The October levels, however, were not different from those of the low nor the high concentration months. There was no significant correlation between HSP 70 expression and water temperature at $20 \mathrm{~m}$ depth $\left(R^{2}\right.$ $=0.26, P=0.07 ; N=13$ ). A significant negative correlation was found between HSP 70 and near bottom seston proteins (Fig. $5 \mathrm{a} ; R^{2}=0.37, P<0.05 ; N=13$ ).

Paramuricea clavata also expressed HSP 90 (constitutive and/or inducible) throughout the seasonal cycle (Fig. 4b). There were differences between the sexes but not between months (Table 1e). Females expressed more HSP 90 protein than males through the annual cycle. Minimum values appeared in June, and maximum in July and January. There was a tendency towards higher HSP 90 concentration in the July to January than in the February to June period. A significant correlation was
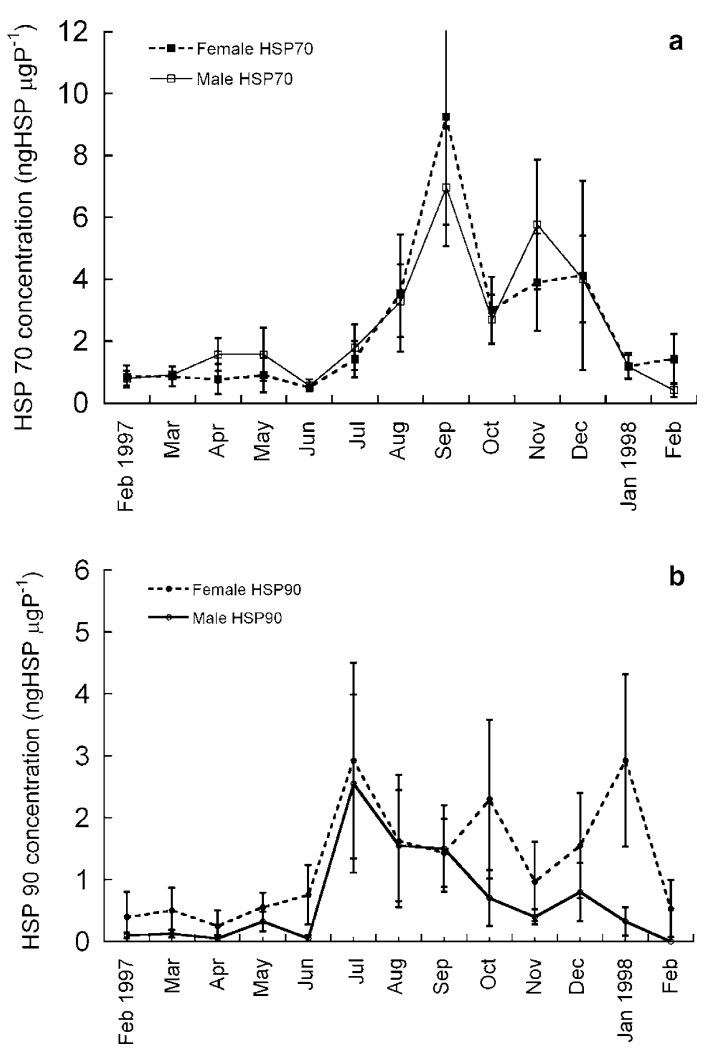

Fig. 4 Expression of heat shock proteins 70 (a) and 90 (b) over 1 year in male and female colonies of Paramuricea clavata (monthly means $\pm \mathrm{SD}$ ) 

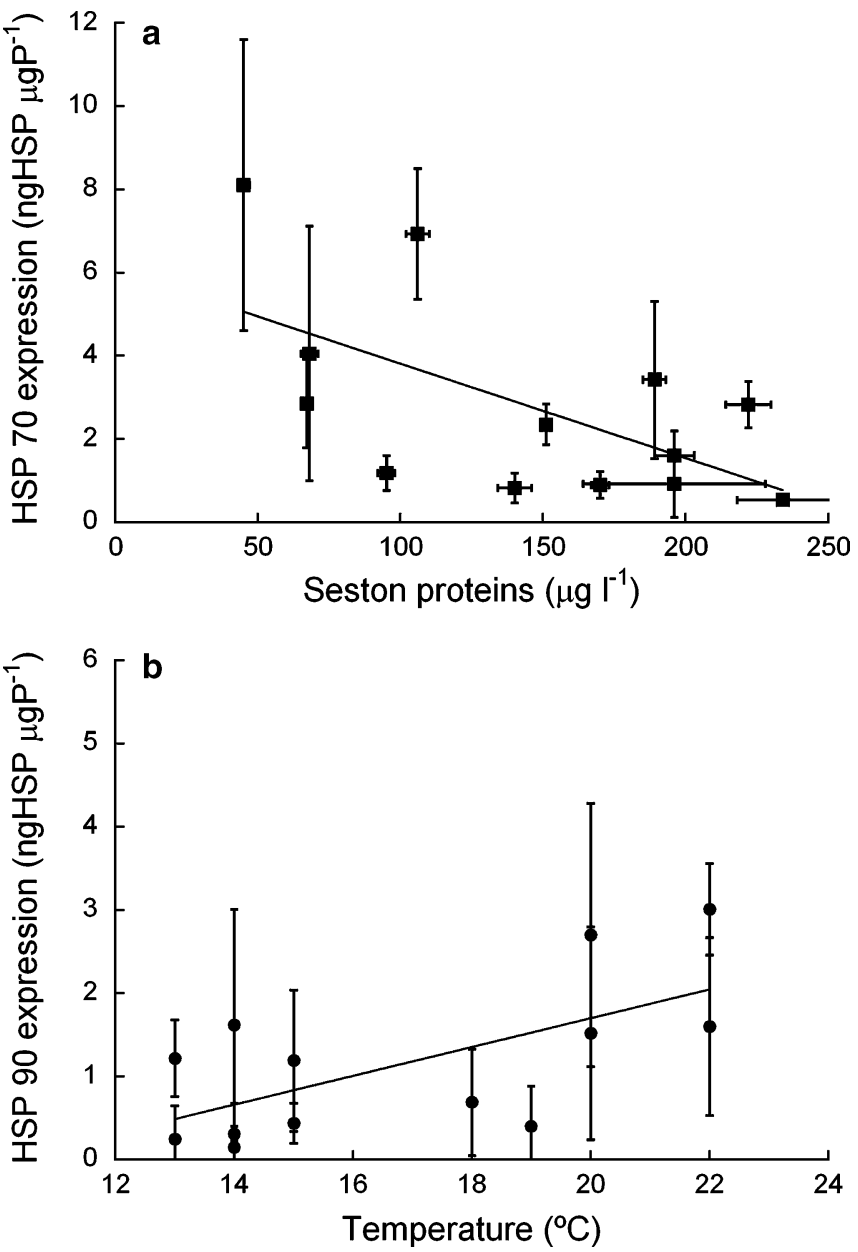

Fig. 5 Relationships between seston protein concentration and HSP 70 expression (a) and between temperature and HSP 90 expression (b); vertical and horizontal bars represent standard deviations

found between HSP 90 expression and water temperature at $20 \mathrm{~m}$ depth (Fig. 5b; $R^{2}=0.42, P<0.02 ; N=13$ ). There was no significant correlation between HSP 90 and near bottom seston proteins $\left(R^{2}=0.14, P=0.20\right.$; $N=13$ ).

HSP 70 expression was higher than HSP 90 expression in the August-December period (two-way ANOVA, $\left.F_{12,197}=5.70, P<0.004\right)$. No significant relationship was found between these two variables $\left(R^{2}=0.02\right.$, $P=0.14 ; N=104)$. The general pattern with a maximum during the summer-autumn period was the same for both stress proteins.

The correlations between biochemical parameters (i.e., carbohydrate and lipid concentrations) and HSP 70 or 90 expressions are shown in Figs. 6 and 7. The best fitting curve was an exponential function (compared with linear, polynomial (orders 2, 3 and 4), and power functions). In order to identify significant relationships, the curves were $\log$ s 10 transformed. Female and male protein levels did not significantly fit with HSP 70 or HSP 90 expression. Male and female carbohydrate levels are inversely associated with HSP 70 and HSP 90 expression (Fig. 6a, b and Fig. 7a, b), showing a significant negative exponential relationship. Male and female lipid levels are significantly related with HSP 70 and HSP 90 (Figs. 6c, d and 7c,d).

\section{Discussion}

Clear seasonal variations in ecophysiological parameters (concentrations of protein, carbohydrates and lipid; expression of HSP 70 and 90) have been observed in the present study: a winter-spring period (with high tissue concentrations of carbohydrates and lipids, and low HSP 70 and 90 expression), and summer-autumn period (with the reverse situation). Seasonal trends in the concentrations of macromolecules and in the expression patterns of HSP 70 and 90 have been the subject of several studies. To our knowledge, the present study is the first for the marine environment reporting on parallel observations on the concentrations of organic macromolecules, stress protein expression and some key environmental parameters (i.e., water temperature, wave height, quantity/quality of near bottom seston). It has been only recently suggested that feeding and HSP 70 expression may be related in marine organisms. Minier et al. (2000) found a direct effect of temperature on HSP 70 expression in Mytilus galloprovincialis, and suggested an indirect effect of food availability and growth. In this study, mussels were permanently submersed, but the sampling site was very shallow and thus shifts in temperature were distinct. The authors found high levels of HSP 78 from July to September, coinciding with increased food availability, which was opposite to our findings for P. clavata. The study was performed in the Ebro river delta, which in summer may have high chlorophyll $a$ levels due to phytoplankton blooms (Camp and Delgado 1987). But the observations by Minier et al. (2000) do not explain whether and how this food enrichment may affect HSP expression, and the only variable that was strongly related with HSP expression was temperature.

In warm temperate seas, a trophic summer crisis related to low food abundance has been demonstrated for some benthic suspension feeders (Sardà et al. 1999; Coma et al. 2000). In the Mediterranean, near bottom seston concentration in summer is low compared to that in winter and spring (Grémare et al. 1997; Rossi et al. 2003). This situation probably explains the low summer levels of lipid and carbohydrate observed in P. clavata tissues. In the present study, near bottom seston protein concentration was relatively high in July-August, but water movement (i.e. wave height) was low. These data suggest a lower food supply to passive suspension feeders in summer, compared with winter-spring time, when the near bottom seston quantity and quality is high and the environment is more turbulent. Water stratification, poor nutrient availability and a low resuspension rate may result in reduced feeding, respi- 

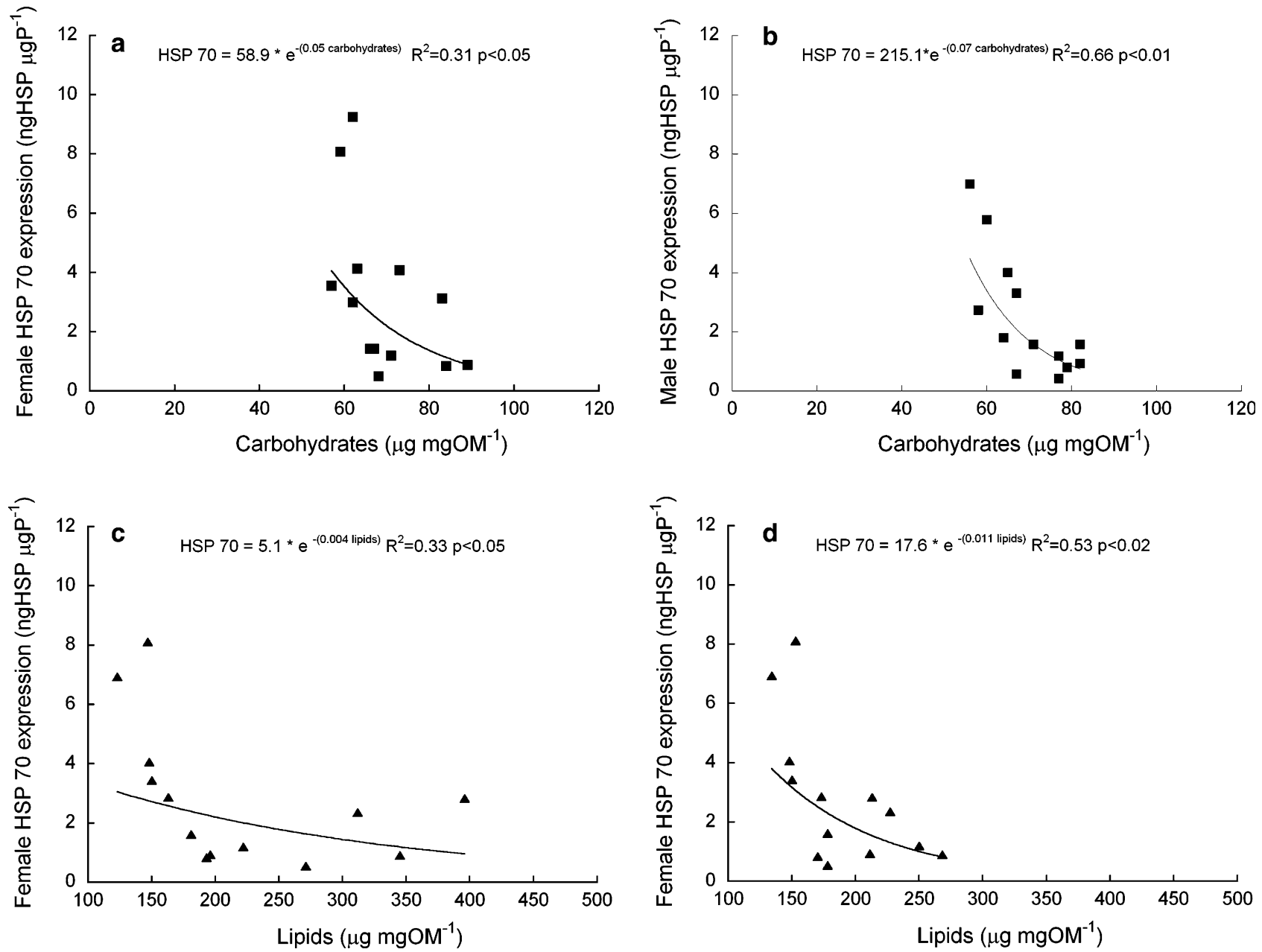

Fig. 6 Expression of HSP 70 in male and female Paramuricea clavata, as an exponential function of the carbohydrate $(\mathbf{a}, \mathbf{b})$ and lipid (c, d) concentrations, respectively

ration and activity of benthic organisms (Sebens 1987). Seston concentration is low in summer, but its quality at this time of the year is very high (Grémare et al. 1997; Rossi et al. 2003). Low autumn carbohydrate-lipid tissue concentrations in P. clavata may also reflect a period of low food availability: seston concentration is very high, but its quality is lower (Grémare et al. 1997; Ribera d'Alcalá et al. 2004; for seston available during the present study see Rossi et al. 2003). Seasonal feeding studies on passive or active suspension feeders in warm temperate seas lead to the conclusion that in autumn, the carbon supply decreases (an important part probably coming directly from low quality detritus, e.g. Ribes et al. 1998; Jordana et al. 2001; Rossi et al. 2004). It cannot be excluded, however, that a decrease in carbohydrate-lipid concentrations in $P$. clavata is associated with reproduction in the summer (Coma et al. 1995b), although non-reproductive colonies of this species show similar seasonal trends (Rossi 2002).

The expression of HSPs also showed seasonal variations. The expression of these proteins cannot be related

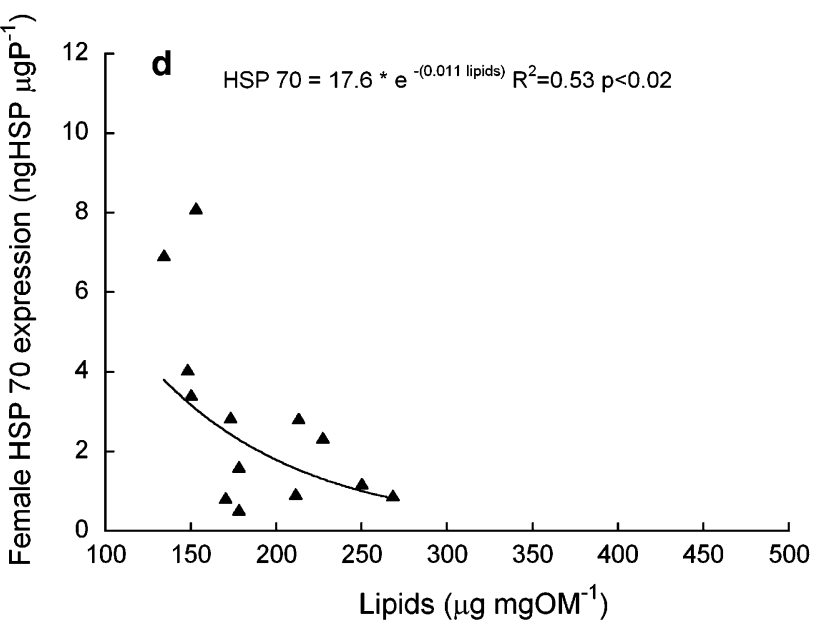

with dramatic temperature shifts. The concentration of lipids as energy storage macromolecules has been related to starvation and reproductive periods in many seasonal studies (e.g. Peck et al. 1987; Cavaletto et al. 1996; Mayzaud et al. 1999), but stress protein expression has so far been related only to heat shocks, i.e., to increases in temperature by $8-15^{\circ} \mathrm{C}$ within a few minutes (e.g., Hofmann and Somero 1995; Helmuth and Hofmann 2001). The present results show that stress protein expression varies through the seasonal cycle: there is a period of low expression in winter-spring and a period of high expression in summer-autumn, coinciding with periods of high and low food availability, respectively. Also, the relationship with near bottom seston quality (proteins) is significant for HSP 70. Plakidou-Dymock and McGivan (1994) demonstrated that HSP 72 was induced in bovine renal epithelial cells deprived of amino acid resources, and Zarsky et al. (1995) showed that in vitro starvation processes in tobacco pollen were accompanied by a dramatic increase in HSP 18. Starvation elevated HSP 42 in Saccharomyces cerevesiae (Wotton et al. 1996), and recently the expression of the HSP 70 family has been linked to starvation in several in vitro experiments involving isolated mammalian cells (Lee et al. 1999; Lewis and Hughes-Fulford 2000). 

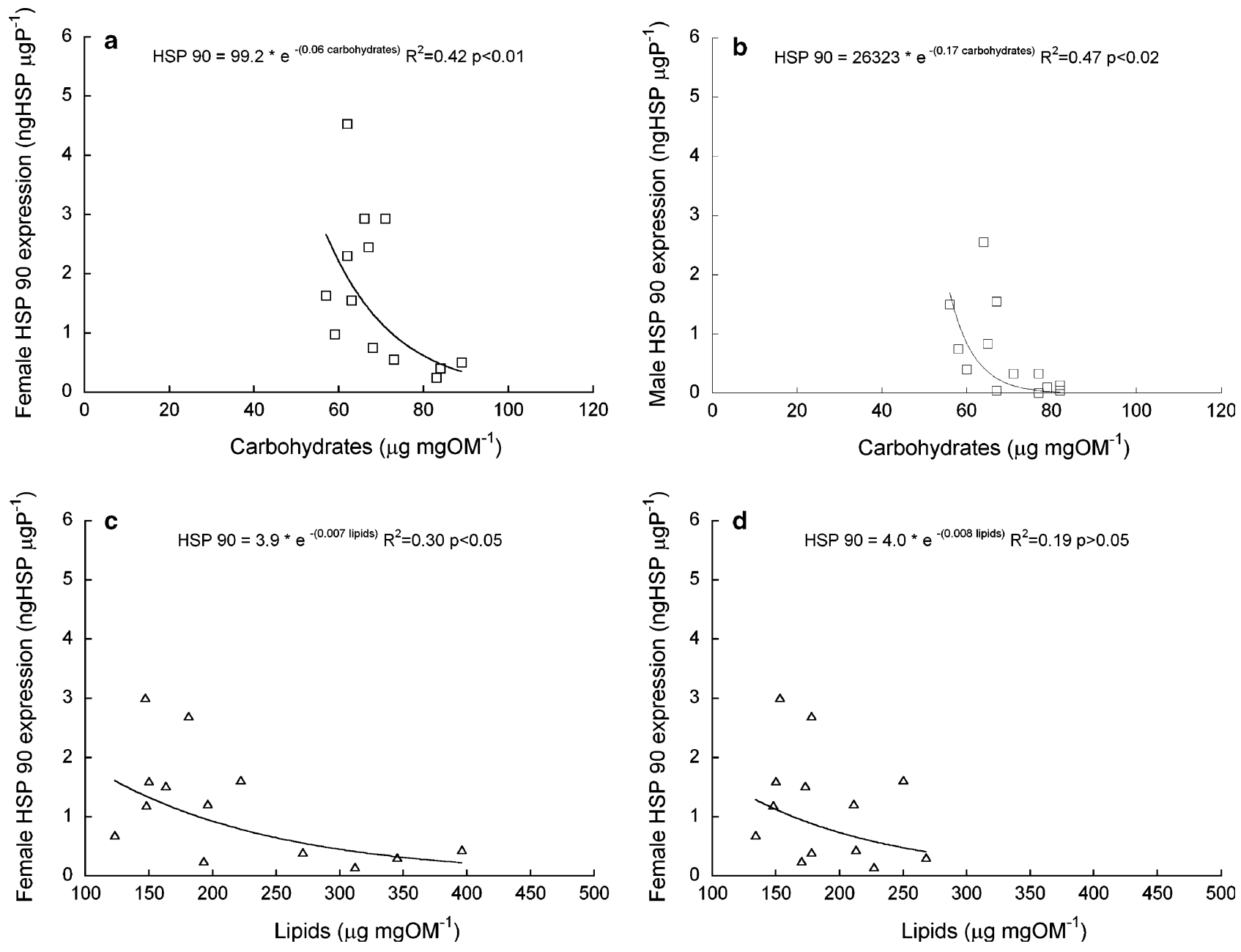

Fig. 7 Expression of HSP 90 in male and female Paramuricea clavata, as an exponential function of the carbohydrate $(\mathbf{a}, \mathbf{b})$ and lipid (c, d) concentrations, respectively

In general, $P$. clavata biological parameters (i.e activity, respiration, etc.) reached low values when lipid and carbohydrate concentrations were low and HSP 70

Table 2 Annual energy budget (energy input-energy output) in Paramuricea clavata

\begin{tabular}{lccccccccccccc}
\hline & Jan & Feb & Mar & Apr & May & Jun & Jul & Aug & Sep & Oct & Nov & Dec \\
& & & & & & & & & & & & & \\
\hline Activity & 8.2 & 9.4 & 8.9 & 8.9 & 7.4 & 8.8 & 1.7 & 3.1 & 7.7 & 8.6 & 6 & 10 \\
Feeding & 59.4 & 61.0 & 57.9 & 81.5 & 88.2 & 75.3 & 25.6 & 33.2 & 27.7 & 33.7 & 66.5 & 99.9 \\
Respiration & 0.52 & 0.58 & 0.65 & 0.81 & 0.98 & 0.83 & 0.68 & 0.57 & 0.46 & 0.42 & 0.38 & 0.45 \\
Reproduction (m) & 0.2 & 1.1 & 4.8 & 41.1 & 88.9 & 46.9 & 0 & 0 & 0 & 0 & 0 & 0.2 \\
Reproduction (f) & 5.3 & 21.3 & 42.8 & 63.2 & 39.2 & 31.5 & 0 & 0 & 0 & 3.5 & 3.5 & 5.3 \\
Tissue growth & 3.2 & 3.2 & 3.2 & 3.2 & 3.2 & 4.0 & 4.6 & 4.0 & 1.6 & 1.6 & 3.2 & 3.2
\end{tabular}

Activity $\left(\mathrm{h} \mathrm{day}^{-1}\right.$ ), from the activity rhythms of Coma et al. (1994) recalculated in Ribes et al. (1999), and Rossi (2002). Feeding (energy input, $\mu \mathrm{g}$ carbon polyp $\left.{ }^{-1} \mathrm{day}^{-1} \times 100\right)$, from the zooplankton fraction (Coma et al. 1994) and the $<100 \mu \mathrm{m}$ detritus and $<100 \mu \mathrm{m}$ live carbon (Ribes et al. 1999). Respiration $\left(\mathrm{mg}^{-1}\right.$ oxygen organic matter tissue $\mathrm{h}^{-1}$ ) from Coma et al. (2002). Reproduction ( $\mu \mathrm{g}$ carbon polyp $^{-1}$ day $^{-1} \times 100 ; \mathrm{m}=$ male and $\mathrm{f}=$ female) from Coma et al. (1995a, 1998b). Tissue growth $\left(\mu \mathrm{g}\right.$ carbon polyp ${ }^{-1}$ day $\left.^{-1} \times 100\right)$ from Coma et al. (1998a, b). All values are means from the above cited works. Non-italicized months indicate the winter-spring period, italicized months the summer-autumn period 
and 90 expressions were high, in coincidence with periods of low food availability (Table 2, Coma et al. 1998a). In winter-spring, polyp expansion, energy input and respiration is higher than in summer-autumn (Table 2). Winter-spring time coincides with the reproductive period, and tissue growth is more regular than in summer-autumn (Table 2). The frequency of food pulses is higher in the winter-spring than in the summerautumn period (Coma et al. 2000), coinciding with the phytoplankton/zooplankton blooms (Estrada 1996; Ribera d'Alcalá et al. 2004). We suggest that HSP 70 and HSP 90 expressions are partly related to the seasonal cycle of food deprivation. Although, temperature was related with HSP 90 expression, we suggest an indirect role of temperature acting through water stratification and the low food supply in summer time. This may be the reason why in autumn, when temperature was lower and water stratification was lacking, the HSPs levels were still high and the lipid and carbohydrate concentrations remained low.

There seems to be a relationship between carbohydrate/lipid concentrations and both HSPs, but there is a wide variability in the present results (Figs. 6,7). These findings might be due to the variability in the feeding success of colonies within the same population. Such variability in the results is not surprising for two reasons: (1) in most studies, stress protein expression is considered a fast physiological response, and the reaction time might vary among colonies of the same patch, and (2) it has been demonstrated in benthic suspension feeders that the feeding rate of a colony depends on its position within the patch (e.g. Okamura 1988). Generally, there seems to be a gradual decrease in the growth rates of gorgonians from the outer to the inner colonies (the outer ones could create trophic shadows on the inner ones; Kim and Lasker 1997).

It appears that the expression of HSP 70 and 90 is more closely related with the concentration of carbohydrates than to those of lipids. Both carbohydrate concentration and HSP 70 and HSP 90 may quickly respond to starvation. The high mobility of carbohydrates under food deprivation is well known (Willmer et al. 2000), and HSPs are rapidly activated in a thermal stress situation (e.g. Hofmann and Somero 1996; Helmuth and Hofmann 2001), and may quickly reduce their levels when stress ceases (Snyder and Rossi 2004). HSPs may become toxic by binding cellular proteins if continuously expressed at high levels (Feder and Hofmann 1999). This may explain the wide variation in the natural $P$. clavata HSP 70 and HSP 90 expression patterns. We suggest that the close relationship of HSPs with carbohydrates rather than with lipids may result from similar responses (i.e., high carbohydrate mobility and rapid HSP induction) during continued starvation. On the other hand, Lee et al. (1999) and Yu and Mattson (1999) found a relationship between a slight reduction in glucose and the expression of HSP 70.

Drastic changes in temperature has been considered to explain rising levels of HSPs, but our results show a situation far from that commonly described in a "heat shock" situation. Feder (1999) emphasized the need of studying HSP expression in a more ecological context in order to understand better how a species physiology adapts to changes in its natural environment. The results of the present paper suggest a relationship between the expression of stress proteins on the one hand, and the tissue concentrations of proteins, carbohydrates and lipids as well as the quality/quantity of available food on the other hand. Further relevant studies in this field might result in a new approach to testing seasonal changes in the fitness of benthic populations.

Acknowledgements We are especially grateful to R. Coma for field assistance, to N. Vert and E. Reyes for laboratory analysis and to $\mathrm{J}$. Pasqual for temperature and wave height data collection. The authors thank T. Packard and R. Coma for their comments on an earlier version of the manuscript. Funding for this work was provided by F.P.I. fellowship from Spain's Ministry of Education and Science to SR under projects DGICYT 1995-1998, PB94-0014C02-01, and by the National Sea Grant College Program, National Oceanic and Atmospheric Administration, US Department of Commerce (grant\#NAO6RGO142, project\# R/CZ-168). The views expressed herein are those of the authors and do not necessarily reflect the views of NOAA or any of its sub-agencies. The US Government is authorized to reproduce and distribute this publication for governmental purposes. The experiments comply with the current Spanish animal experimental and manipulation laws.

\section{References}

ACA (2001) Seguiment de la qualitat de l'aigua a la zona del Baix Empordà: platja de l'Estartit. In: Balanç de Resultats de la qualitat de l'aigua costanera del Període 1990-2000 a la Costa Catalana, pp 153-154

Arin L, Berdalet E, Marrasé C, Estrada M, Guixa-Boixereu N, Dolan J (1999) Particulate DNA and protein relative to microorganism biomass and detritus in the Catalano-Balearic sea (NW Mediterranean) during stratification. J Plank Res 21:1299-1316

Barnes H, Blackstock J (1973) Estimation of lipids in marine animals tissues: detailed investigation of the sulphophosphovanillin method for "total" lipids. J Exp Mar Biol Ecol 12:103-118

Black NA, Voellmy R, Szmant AM (1995) Heat shock protein induction in Monastraea faveolata and Aiptasia pallida exposed to elevated temperatures. Biol Bull 188:234-240

Brockington S, Clarke A, Chapman ALG (2001) Seasonality of feeding and nutritional status during the austral winter in the Antarctic sea urchin Sterechinus neumayeri. Mar Biol 139:127138

Camp J, Delgado M (1987) Hidrografía de las bahías del Delta del Ebro. Inv Pesq 51:351-369

Cavaletto JF, Gardner WS (1998) Seasonal dynamics of lipids in freshwater benthic invertebrates. In: Arts M, Wainman B (eds) Lipids in freshwater ecosystems. Springer, New York, pp 109131

Cavaletto JF, Nalepa TF, Dermott R, Gardner WS, Quigley MA, Lang GL (1996) Seasonal variation of lipid composition, weight and length in juvenile Diporeia spp (Amphipoda) from Lakes Michigan and Ontario. Can J Fish Aquat Sci 53:2044 2051

Cebrián J, Duarte CM, Pascual J (1996) Marine climate on the Costa Brava (northwestern Mediterranean) littoral. Publ Espec Inst Esp Ocenogr 22:9-21

Coma R, Gili JM, Zabala M, Riera T (1994) Feeding and prey capture cycles in the aposymbiontic gorgonian Paramuricea clavata. Mar Ecol Prog Ser 115:257-270 
Coma R, Ribes M, Gili JM, Zabala M (1995a) Reproduction and cycle of gonadal development in the Mediterranean gorgonian Paramuricea clavata. Mar Ecol Prog Ser 117:173-183

Coma R, Zabala M, Gili JM (1995b) Sexual reproduction in the Mediterranean gorgonian Paramuricea clavata. Mar Ecol Prog Ser 117:185-192

Coma R, Ribes M, Gili JM, Zabala M (1998a) An energetic approach to the study of life-history traits of two modular colonial benthic invertebrates. Mar Ecol Prog Ser 162:89-103

Coma R, Ribes M, Zabala M, Gili JM (1998b) Growth and partial mortality in the Mediterranean gorgonian Paramuricea clavata. Estuar Coastal Shelf Res 47:459-470

Coma R, Ribes M, Gili JM, Zabala M (2000) Seasonality in coastal benthic ecosystems. Trends Ecol Evol 15:448-453

Coma R, Ribes M, Gili JM, Hughes RN (2001) The ultimate opportunists: consumers of seston. Mar Ecol Prog Ser 219:305308

Coma R, Ribes M, Gili JM, Zabala M (2002) Seasonal variation of in situ respiration rate in temperate benthic suspension feeders. Limnol Ocenogr 47:324-331

Dubois M, Gilles KA, Hamilton JK, Rebers PA, Smith F (1956) Colorimetric method for the determination of sugars and related substances. Anal Chem 28:350-356

Estrada M (1996) Primary production in the northwestern Mediterranean. Sci Mar 60:55-64

Fang L, Huang SP, Lin KI (1997) High temperature induces the synthesis of heat-shock proteins and the elevation of intracellular calcium in the coral Acropora grandis. Coral Reefs 16:127-131

Feder ME (1999) Organismal, ecological, and evolutionary aspects of heat-shock proteins and the stress response: established conclusions and unresolved issues. Am Zool 39:857-864

Feder ME, Hofmann GE (1999) Heat-shock proteins, molecular chaperones, and the stress response: evolutionary and ecological physiology. Annu Rev Physiol 61:243-282

Gili JM, Ros J (1985) Study and cartography of the benthic communities of the Medes Islands (NE Spain). PSZNI: Mar Ecol 6:219-238

Gili JM, Coma R (1998) Benthic suspension feeders: their paramount role in littoral marine food webs. Trends Ecol Evol 13:316-321

Grémare A, Amouroux JM, Charles F, Dinet A, Riaux-Gobin C, Baudart J, Medernach L, Bodiou JY, Vétion G, Colomines JC, Albert P (1997) Temporal changes in the biochemical composition and nutritional value of the particulate organic matter available to surface deposit-feeders: a two year study. Mar Ecol Prog Ser 150:195-206

Helmuth BST, Hofmann GE (2001) Microhabitats, thermal heterogeneity, and patterns of physiological stress in the rocky intertidal zone. Biol Bull 201:374-384

Hofmann GE, Somero GN (1995) Evidence for protein damage at environmental temperatures: seasonal changes in levels of ubiquitin conjugates and HSP70 in the intertidal mussel Mytilus trossulus. J Exp Biol 198:1509-1518

Hofmann GE, Somero GN (1996) Protein ubiquitination and stress protein synthesis in Mytilus trossulus occurs during recovery from tidal emersion. Molec Mar Biol Biotechnol 5:175-184

Jordana E, Grémare A, Lantoine F, Courties C, Charles F, Amouroux JM, Vétion G (2001) Seasonal changes in the grazing of coastal picoplankton by the suspension-feeding polychaete Ditrupa arientina (O.F. Müller). J Sea Res 46:245-259

Kim K, Lasker HR (1997) Flow-mediated resource competition in the suspension feeding gorgonian Plexaura homomalla (Esper). J Exp Mar Biol Ecol 215:49-64

Laemmli UK (1970) The cleavage of structural proteins during assembly of the head of bacteriophage T4. Nature 227:680-685

Lee J, Bruce-Keller AJ, Kruman Y, Chan SL, Mattson MP (1999) 2-Deoxy-D-glucose protects hippocampal neurons against excitotoxic and oxidative injury: evidence for the involvement of stress proteins. J Neur Res 57:48-61

Lewis ML, Hughes-Fulford M (2000) Regulation of heat shock protein message in Jurkat cells cultured under serum-starved and gravity-altered conditions. J Cell Biochem 77:127-134
Lowry OH, Rosebrough NJ, Farr AL, Randall RJ (1951) Protein measurement with the Folin phenol reagent. J Biol Chem 193:265-275

Mayzaud P, Virtue P, Albessard E (1999) Seasonal variations in the lipid and fatty acid composition of the euphasiid Meganyctiphanes norvegica from the Ligurian sea. Mar Ecol Prog Ser 186:199-210

Miller D, Brown BE, Sharp VA, Nganro N (1992) Changes in the expression of soluble proteins extracted from the symbiotic anemone Anemonia viridis accompany bleaching induced by hyperthermia and metal stressors. J Therm Biol 17:217-223

Minier C, Borghi V, Moore MN, Porte C (2000) Seasonal variation of MXR and stress proteins in the common mussel, Mytilus galloprovincialis. Aquat Toxicol 50:167-176

Mistri M, Ceccherelli VU (1994) Growth and secondary production of the Mediterranean gorgonian Paramuricea clavata. Mar Ecol Progr Ser 103:291-296

Okamura B (1988) The influence of neighbors on the feeding of an epifaunal bryozoan. J Exp Mar Biol Ecol 120:105-123

Pascual J, Lloret L, Salat J, Zabala M (1995) Projecte de determinació de la circulació de les aigües de la Reserva Marina de les Illes Medes. Informe técnic per la Direcció General de Pesca Marítima, Generalitat de Catalunya

Peck LS, Clarke A, Holmes LJ (1987) Summer metabolism and seasonal changes in biochemical composition of the Antarctic brachiopod Lyothyrella uva (Broderip 1833). J Exp Mar Biol Ecol 114:85-97

Plakidou-Dymock S, McGivan JD (1994) Amino acid deprivationinduced stress response in the bovine renal epithelial cell line NBL-1: induction of HSP 70 by phenylalanine. Biochem Biophys Acta 1224:189-197

Ribera d'Alcalá M, Conversano F, Corato F, Licandro P, Mangoni O, Marino D, Mazzocchi MG, Modigh M, Montresor M, Nardella M, Saggiorno V, Sarno D, Zingone A (2004) Seasonal patterns in plankton communities in a pluriannual time series at a coastal Mediterranean site (Gulf of Naples): an attempt to discern recurrences and trends. Sci Mar 68(Suppl 1):65-83

Ribes M, Coma R, Gili JM (1998) Seasonal variation of in situ feeding rates by the temperate ascidian Halocyntia papillosa. Mar Ecol Prog Ser 175:201-213

Ribes M, Coma R, Gili JM (1999) Heterogeneous feeding in benthic suspension feeders: the natural diet and grazing rate of the temperate gorgonian Paramuricea clavata (Cnidaria: Octocorallia) over a year cycle. Mar Ecol Prog Ser 183:125-137

Rossi S (2002) Environmental factors affecting the trophic ecology of benthic suspension feeders. PhD Thesis, University of Barcelona

Rossi S, Snyder MJ (2001) Competition for space among sessile marine invertebrates: changes in HSP 70 expression in two Pacific cnidarians. Biol Bull 201:385-393

Rossi S, Grémare A, Gili JM, Amouroux JM, Jordana E, Vétion G (2003) Biochemical characteristics of settling particulate organic matter at two north-western Mediterranean sites: a seasonal comparison. Estuar Coastal Shelf Sci 58:423-434

Rossi S, Ribes M, Coma R, Gili JM (2004) Temporal variability in zooplankton prey capture rate of the soft bottom passive suspension feeder Leptogorgia sarmentosa (Cnidaria: Octocorallia), a case study. Mar Biol 144:89-99

Sardá R, Pinedo S, Martín D (1999) Seasonal dynamics of macroinfaunal key species inhabiting shallow soft-bottoms in the bay of Blanes (NW Mediterranean). Acta Ecol 20:315-326

Sebens KP (1987) Coelenterata. In: Pandian TJ, Vernberg FJ (eds), Animal energetics. 1. Academic, San Diego, pp 55-120

Sharp VA, Miller D, Bythell JC, Brown BE (1994) Expression of low molecular weight HSP 70 related polypeptides from the symbiotic sea anemone Anemonia viridis Forskall in response to heat shock. J Exp Mar Biol Ecol 179:179-193

Sharp VA, Brown BE, Miller D (1997) Heat shock protein (HSP 70) expression in the tropical reef coral Goniopora djiboutiensis. J Therm Biol 22:11-19

Slattery M, McClintock JB (1995) Population structure and feeding deterrence in three shallow-water Antarctic soft corals. Mar Biol 122:461-470 
Snyder MJ, Mulder EP (2001) Environmental endocrine disruption in decapod crustacean larvae: hormone titers, cytochrome P450, and stress proteins. Aquat Toxicol 55:177-190

Snyder MJ, Rossi S (2004) Regulation of stress protein (HSP70 family) expression in intertidal benthic organisms: the example of Anthopleura elegantissima (Cnidaria: Anthozoa). Sci Mar 68 (Suppl 1):155-162

Snyder MJ, Girvetz E, Mulder EP (2001) Stress protein induction by chemical exposures in molluscs. Arch Environ Contam Toxicol 41:22-29

Weinberg S (1978) Mediterranean octocorallian communities and the abiotic environment. Mar Biol 49:41-57

Wiens M, Ammar MSA, Nawar AH, Koziol C, Massanein HMA, Eisinger M, Müller IM, Müller WEG (2000) Induction of heatshock (stress) protein gene expression by selected natural and anthropogenic disturbances in the octocoral Dendronephyta klunzingeri. J Exp Mar Biol Ecol 245:265-276

Wildish D, Kristmanson D (1997) Benthic suspension feeders and flow. Cambridge University Press, Cambridge
Willmer P, Stone G, Johnston I (2000) Environmental physiology of animals. Blackwell, Oxford

Wotton D, Freeman K, Shore D (1996) Multimerization of HSP $42 p$, a novel heat shock protein of Saccharomices cerevesiae, is dependent on a conserved carboxyl-terminal sequence. The $\mathbf{J}$ Biol Chem 271:2717-2723

Wotton RS (1994) Methods of capturing particles in benthic animals. In: RS Wottom (ed) The biology of particle in aquatic systems. Lewis Publishers, Boca Raton, pp 183-204

Yu ZF, Mattson MP (1999) Dietary restriction and 2-deoxyglucose administration reduce focal ischemic brain damage and improve behavioural outcome: evidence for a preconditioning mechanism. J Neur Res 57:830-839

Zarsky V, Garrido D, Eller N, Tupy J, Vicente O, Schoffl F, Heberle-Bors E (1995) The expression of a small heat shock gene is activated during induction of tobacco pollen embryogenesis by starvation. Plant Cell Environ 18:139-147 